\title{
EVIDENCE-BASED HRM THROUGH ANALYTICS: REDUCING THE PROPENSITY OF HRM TO BECOME A CINDERELLA
}

\author{
Vincent Cassar, Frank Bezzina \\ University of Malta \\ e-mails: vincent.cassar@um.edu.mt; frank.bezzina@um.edu.mt \\ DOI: $10.15611 /$ noz.2017.4.01 \\ JEL Classification: M540
}

\begin{abstract}
Summary: HRM practitioners often struggle to adopt a strategic function in their organization. Borrowing from evidence-based management, this paper highlights the importance of data for enabling better HRM decision-making as irregular decision-making processes can lead to mistakes. Often managers lack the time to evaluate the data and/or have incomplete data. Unfortunately, studies indicate that HRM practices are still heavily based on popular knowledge, misconceptions and behavioural/strategic assumptions of "what should work best'. Yet increasingly literature concedes that HRM practices impact performance and the relationship is by and large universal, thus demanding improved decisions through the relevant use of data which has been discussed for many years. The paper addresses important points in HRM analytics and emphasises that this requires HR practitioners to develop three important skill sets: an understanding of data treatment and analysis, the use of IT and knowledge of other business areas since like other fields of management, HRM is evolving and needs to adapt to changes at work to become more strategically relevant.
\end{abstract}

Keywords: HRM practitioners, HRM metrics, HRM analytics, decision-making, data, evidence-based HRM.

\section{Introduction}

In our experience with MBA and doctoral students, we are often confronted with the feeling that of all the fields of Management that of Human Resource Management (HRM), in particular, seems to be considered the 'easiest' of the options. Most students would testify that HRM is considered as the 'softer' part of management, that managing people is a gift and an art and all it takes is a good dose of compassion and perhaps empathy to listen to and address their needs and 'align' those to the needs of business. HRM, they would further comment, is learning to put a number of 'tools' (like recruitment and selection, employment law, performance appraisals, etc.) within a practical framework that can be easily adopted and applied. In addition, they would admit that HRM is the first 'function' to be downsized in times of business distress, and they would admit that in general HRM managers have little 'evidence' to show and convince about their decisions at Board level.

The reality is that very often HRM practitioners struggle to serve a strategic purpose in their organi- zation. This has been noted and reported by many, for example Pfeffer and Sutton [2006, p. 25] stated: "Yet as we talk to senior HR executives trying to lead their organisations through these transformations - we see continuing struggles and setbacks in their efforts to implement these changes". Rousseau and Barends [2011, p. 223] have hinted that: "The need to rethink conventional HR practice is urgent. Recent events add further complexity to challenges that by themselves would test the acumen of any expert or practitioner: economic meltdowns, failed business models and deteriorating organisational capacities to forecast and manage risk and adapt effectively to market changes". More recently, Briner and Barends [2016, p. 18] have stated that: "In HR it can seem we are not particularly good at distinguishing between reasonably sound evidence and weak, dubious and downright nonsense claims". These admissions highlight the lack of rigidity and conviction pertaining to this fundamental practice in organizations; indeed portraying an image of a neglected and wretched Cinderella.

The implications of these thoughts is that many still view HRM as an art, a liberal art at that, rather 
than a practising field that can benefit, and in addition, profit from the rich scientific evidence that has shaped the management of people in organizations (c.f. [Porter, Schneider 2014]). While it is true that HRM has evolved from a mere administrative role to a more strategic one (c.f. [Dik, Byrne, Steger 2013; Gratton 2000]), a number of investigations and debates argue about the 'loose' nature of the HRM field and there are calls to tighten it up even more as a profession through using practices and techniques that are grounded in the evidence [Hirsh, Briner 2011].

This paper continues to profess this line of thought and aims to highlight the need for HRM practitioners to endorse a more evidence-based analytic-approach in their professional practice towards making effective decisions; it also makes the claim that more research is needed to understand how HRM can benefit from the evidence in shaping people-oriented decisions in organizations, thus rescuing the HRM Cinderella image from the dustbin and letting it be invited to the Management Ball.

This paper is divided into five sections. Given that analytics is based on data which is transformed into important information in decision making, the first section presents a brief overview of Evidence-Based Management (EBM). This serves as our canvas on which to sketch our remaining argument. We then present a number of studies that illustrate the lack of usage of evidence by HRM practitioners. On the basis of these findings we reflect upon the relevance of HRM practices on firm performance and then proceed to stress the need to ensure that HRM and people management is governed by more rigorous and datadriven practices that provide superior predictive explanations. To this end, we introduce the role of analytics in HRM and finally present a number of issues of relevance to this stream of thought and highlight the competency areas required by HRM practitioners to be enabled and conversant with the use of analytics.

\section{A brief overview of Evidence-Based Management}

In the early 1990s, two physicians at McMasters University in Canada (David Sackett and Gordon Guyatt) challenged the traditional teaching of medicine to students by reporting on their 'bedside teaching' technique. Although the medical community of the time was less than lukewarm towards this new paradigm of medical education, evidence-based medicine eventually became the teaching norm in medical schools across Canada, the US and to a certain extent in the UK. Evidence based approaches followed suit in other fields like policy development, environmental studies and industrial chemistry. However, in management education, the 'revolution' of how and why managers adopt specific practices as opposed to others remains mostly an art in the most raw form and subject to misconceptions, cognitive biases and personal preferences for methods that seem to work only in the eyes of the beholder. William Edwards Deming is credited with the dictum: 'Without data you're just another person with an opinion'. Evidence is information; information generates knowledge; and knowledge is power. Ensuring that information is reliable and valid is the challenge of every manager who acknowledges that there is little use for unreliable and/or invalid information to support decisionmaking. Briner, Denyer and Rousseau [2009, p. 19] define EBM as the process of "... making decisions through the conscientious, explicit, and judicious use of four sources of information: practitioner expertise and judgment, evidence from the local context, a critical evaluation of the best available research evidence, and the perspectives of those people who might be affected by the decision".

This definition should draw several reflections. The first is that EBM is a non-random and orderly process of systematically making sense of the information available. In fact EBM provides the tools to critically evaluate and extract the best quality of information from different sources that managers access in order to reduce the uncertainties around any decision that matters [Barends, Rousseau, Briner 2014]. Relying on old or tried and tested tested formulae is not necessarily the 'best' and neither is there any guarantee for managers that depending on old formulae offers reliable results. The second is that EBM is based on information that is derived from multiple sources including research, organizational data, stakeholders and managerial experience. For example, in the case of research, Rousseau [2006] postulates that this approach to management will help to close the gap between research and practice. Rousseau and McCarthy [2007] indicate that a reliance on science involves a sequence of three important steps: first - developing awareness in professional decision practice; second - diagnosing the underlying factors related to decisions; third developing and contextualizing the knowledge derived from the available evidence. Likewise, in the case of organizational data, Donaldson [2012] argues that using organizational data to generate inferences means adopting a critical eye on the soundness of such data and the avoidance of common traps such as small numbers and error variance within the quality of data collected. The third reflection, and perhaps the 
most important one (it is in fact implicitly embedded in the previous two) is that decisions lie at the core of EBM as much as making decisions lies at the heart of management practice [Baba, HakemZadeh 2012]. Because decisions bear monetary, time and resources implications, they are an important foundation for managers' learning [Rousseau 2006]. We live in a business environment where the market topography is complex, filled with challenges, uncertainties and therefore risks [Bhalla, Dyrchs, Strack 2017]. This topography is increasingly in need to undo failed business models and to develop new organizational capacities to forecast and manage risk in the process of adaptation. Hofmann and Frese [2011] postulate that learning how people make decisions, evaluate risks, and take action should be a prime purpose of investigation of management scholars and researchers, especially in a world driven by huge masses of information. Thus for managers' decisions to rely on plausibility rather than accuracy is a recipe for disaster. This notion concords with Weick's [1995] work that proposes seven properties of sense-making behaviour. Sense-making partly involves the formation of reasoning that is not necessarily correct but seems to fit the facts at that moment in time without the effort to break down the decision-processes into smaller and complete chunks. Sense-making happens either because managers lack the time to evaluate the data or have incomplete data or both. Pfeffer and Sutton [2006] observe that it is not unusual for managers to neglect new evidence and to base their decisions on dogma and belief.

\section{People Management: Is it evidence-driven?}

Having provided a brief overview of what EBM is about, we now shift our attention specifically to HRM. Most of the research seems to suggest that in spite of the importance of HRM to organizational competitiveness [Jackson, Schuler, Jiang 2014], HRM practices are still heavily based on popular knowledge, misconceptions and behavioural/strategic assumptions of 'what should work best' as already hinted at above. This pattern is quite universal and not constrained to practitioners in any one part of the world. Let us take a look at some of the more prominent studies in this regard.

The first study conducted by Rynes, Colbert and Brown [2002] clearly revealed that HRM managers from the US and other settings do have a number of irregular beliefs about specific researched human resource topics and will rely on what they guess should work best. The authors concluded that one of the main reasons for the propagation of irregular beliefs is attributable to the lack of knowledge held by the practitioners. In another study, Briner [2007] investigated managers' decision making and found that particularly in management sectors like HRM, managers often rely on a quick fix due to the large mass of evidence that often makes it difficult for managers to be more evidence-based (e.g. [Pfeffer, Sutton 2006]). In addition, Sanders, van Riemsdijk and Groen [2008] assessed the gap between research and practice amongst Dutch participants. Their results replicate more or less the previous findings (e.g. [Rynes et al. 2002]) and suggest that there are large discrepancies between what the evidence states and what the practitioners believe, especially in areas related to recruitment and selection. Barends, Villanueva, Briner and S. ten Have [2015] surveyed more than 1500 management practitioners in Belgium, the Netherlands and the US. In general, their findings reveal that time to consult the evidence is the main barrier for translating research into practice, and this is mostly attributed to the non-readability of the academic materials and journals. More recently, Bezzina, Cassar, Tracz-Krupa, Przytula and Tipuric [2017] examined this pattern of findings about HRM practices amongst practitioners in Poland, Croatia and Malta and found that they had a number of misconceptions related to evidence-based principles of people management ranging from $26 \%$ to $86 \%$ of the issues being misconceived by the participants in the study. Moreover, HRM practitioners stated that they are more likely to access required knowledge for applications through popular sources rather than more reliable ones due to time constraints, inaccessibility and inability to evaluate the evidence.

Therefore the general picture that emerges from these studies is essentially one that HRM, in spite of its importance, is still very much the practice field of a wide array of professionals covered by practices that are not necessarily evidence-driven and by 'practitioners' who have a wide array of manners to conduct the HRM job without a precise approach, but can this state of affairs remain the way it is? In order to answer this question, it is important to first indicate the increasing strategic relevance of HRM in a new, but complex, world of work.

\section{HRM and the new world of work}

In many ways this is not a new topic. A great number of authors have treated this subject since the 1990s and through the initial millennial years [Bridges 1995; Herriot, Pemberton 1995]. This shift of conceptualising work, one based on a new deal [Sparrow, Cooper 
2003], has meant that the classification of work has undergone a change in the manner we categorise it. Cappelli and Keller [2013] have reviewed archetypal models of full-time work and scholars are becoming increasingly aware that the organization of work and the broader context in which work takes place have tremendous implications for how management, not least HRM, think about and assess individual, managerial, and organizational outcomes [Ashford, George, Batt 2007; Grant, Parker 2009; Humphrey, Nahrgang, Morgeson 2007]. In a similar vein, but from a slightly different perspective, Kipping and Üsdiken [2014] give credit to the evolution of management as it relates to the theoretical development of an organization with implications on the conceptualization of 'organization' and therefore its management. Within this context of evolving organizations and reconceptualization of 'work', HRM has often been considered as a central element that drives the organization towards its general objectives and performance targets [Ostroff, Bowen 2016]. Bowen and Ostroff [2004] in fact refer to the construct of HRM system strength. This refers to how an HRM system is designed and administered effectively by defining strong practising components that collectively create a strong situation in the form of shared meaning about the content [including data] that might ultimately be used to impact organizational performance. They argue that HRM practices can be seen as a means of communication between the employer and employee. This way of thinking shifted attention in the HRM field from what elements of HRM potentially affect employee and firm performance, to how HRM as a system affects performance as part of a broader strategic process.

According to Farndale and Sanders [2017], 'HRM system strength' is not universal but rather subject to national cultural differences. According to the authors, while research demonstrates that both individual HRM practices such as recruitment and selection, pay (for performance), training, and performance appraisal [Combs et al. 2006; Jiang et al. 2012], as well as bundles of HRM practices, are effective in terms of employee and firm performance, this is not always the case and their model argues that national culture dimensions - including power distance, uncertainty avoidance, performance orienta-tion, and in-group collectivism - should be considered as examples of contingency factors when theorizing the outcomes of HRM system strength. We argue that these (and potentially other) national culture dimensions ultimately influence employee perceptions and the understanding of HRM in their organization even though certain misconceptions are shared as seen in the previous section. This implies that while HRM represents a specific set of tools available to practitioners to render their organization more effective, there seems to be no universal yardstick as to what represents a benchmark.

This seemingly contingent nature of 'effective HRM practices' however, does not preclude that the impact of HRM practices has some sort of 'effect' on performance even though the extent may vary as implied by the HRM system strength. In fact scholars maintain that context (e.g. industry, strategy, culture) is largely irrelevant when examining the relationship between HRM and performance relationship [Farndale, Sanders 2017]. In other words, the proponents of the universal perspective of HRM maintain that a bundle of HRM practices exists that will be effective in enhancing performance in any given situation [Pfeffer 1998]. Indeed, the majority of research in this field adopts this universal perspective. Moreover, Delery and Doty [1996] concluded in support of the universal perspective of HRM when reporting that the effect of HRM on performance is not contingent on firm strategy. More recently, Clinton and Guest [2013] also argued for a universal perspective on HRM after discovering that the effect of HRM on commitment, intention to quit, and employee well-being did not differ significantly across the job level, which they identified as an internal contingency factor. This is generally good news as it means that adopting specific standard HRM practices are likely to yield the same results, irrespective of the industrial sector or culture and which can be promoted as best practices to provide the best predictive results on performance, it also means that HRM has a valuable future. Moreover, the use of information technology systems to record HRM practices, trends and data may not only revolutionize the management of people but also evaluate more precisely and more comparably their outcomes and the beneficial impact on organizations [Bondarouk, Brewster 2016] making such HRM practices better comparable and, at the same time, versatile. But is this the case? In this context, one ponders on the need to develop HRM practices with enhanced analytics through specific metrics. It is to this specific issue that we now turn.

\section{HRM Analytics}

The point of departure for our argument is based on the simple but powerful premise that has already been stated earlier on: decisions lie at the core of 'management' and (organizational) data is a sure resource for decision-making as indicated in the 
definition of EBM [Briner et al. 2009]. Turning data from HRM practices into information and knowledge that is applicable is often not direct or straightforward and therefore does not come easily. For example, noting a remarkable high percentage of people leaving the organization is not directly tantamount to low satisfaction, unless other data corroborates that conclusion. At that point, the data becomes more informative and tells us something that we may not have known before. While these are interlinked processes, they exist in a perpetual cyclical fashion. Transforming data into information and knowledge is developmental and sequential. Managers adopt a degree of selective attention to the most appropriate and valid data that can elicit applicable results because not all the information gathered can be justified with a favourable level of good evidence. Moreover, translating information through evidence into practice requires closing the gap between what is known and what is practised. Turning data into evidence, and in turn into practice is a process of critical thought, insightful reflection and active questioning. It also involves an intensive assessment of a host of factors, not least cultural [Farndale, Sanders 2017], contextual [Baba, HakemZadeh 2012] and natural judgemental biases in the process of decision making [Bazerman, Moore 2013]. As suggested earlier, studies indicate that the situation is more fluid and more relaxed when it comes to fields like HRM [Briner et al. 2009; Rousseau 2007; Latham 2007].

One way to overcome this may be the introduction of more hard evidence and improved data that supports the decision-making process. Indeed, over the last few years a number of initiatives have taken place and a number of practitioner-oriented tools have been published to support HRM to become more datadriven and focused on internal assessments of specific HRM analytics (e.g. [Bassi, Carpenter, McMurrer 2012; Burkholder, Golas, Shapiro 2007; Edwards, Edwards 2016; Fitz-Enz 2010; Smith 2013]).

Before we proceed to an evaluation of an 'HRM data' culture, it is right to remind ourselves that this is only one, albeit significant, perspective of enacting a strategic HRM approach. This is only fair to point out in view of the criticisms directed at EBM in the field of HRM [Learmonth 2006; Learmonth, Harding 2016]. Indeed, it is warranted to argue that an HRM system goes beyond the hard and fast evidence and therefore cannot be easily translated into mere 'assessments' and 'analytics'. To begin with, HRM systems become alive through the social interactions among the many organizational members who act as the 'consumers' of this system ranging from HRM professionals, employees and managers in other departments [Jackson, Schuler 2003]. In addition, one cannot not contextualise HRM. Organizations are dynamic entities and given that organisations are constantly in flux, an organization's external and internal environments create a dynamic context for the development, evolution and demise of HRM policies and practices [Jackson et al. 2014]. Lastly, HRM systems are subject to the influence of multiple stakeholders that can mould and shape its 'state' from a variety of perspectives such as the standing of the profession, social criteria embodied in laws and regulations and individual employee reactions [Jackson et al. 2014]. Hence, 'data' relevant to and generated by HRM practices should be considered as one (important) piece in a jigsaw puzzle; the challenge remains to raise further the bar and to signify further their relevance. We now turn our attention to an evaluation of HRM analytics.

\section{Evaluation of HRM Analytics}

'HRM Analytics' represents a new innovation even though it has been discussed for many years. Lawler, Levenson and Boudreau (2004) distinguish 'HRM Analytics' as separate from 'HRM metrics'. Lawler et al. [2004], state that analytics are not measures but rather represent statistical techniques and experimental approaches that can be used to show the impact of HRM activities. Indeed, Bassi [2011] argues that HRM analytics consists of an array of tools and technologies, ranging from the simple reporting of HRM metrics all the way up to predictive modelling and can be considered both as "systematically reporting on an array of HR metrics' or more sophisticated solutions, based on 'predictive models' and 'what-if scenarios'. In addition, Bassi's definition includes the notion of taking an 'evidence-based approach' to making decisions on the 'people side of the business'. Finally, focusing on the link with strategic HRM, Mondare, Douthitt, and Carson [2011] define HRM analytics as demonstrating the direct impact of people on important business outcomes. Despite this distinction between HRM metrics and HRM analytics, there still is definitional ambiguity in the literature. However, because we discuss here the processes of deriving and treating the data from organizations, we prefer to use the term 'HRM analytics'.

There are several points one ought to highlight in HRM analytics. The first is that HRM analytics is not HRM Metrics; better still, the latter represent a subset of the former. Metrics, in this sense, are measures of key HRM outcomes, classified as efficiency, effectiveness or impact. Thus analytics represent more an approach, a methodology and a way of 
treating important information rather than a static yardstick or a signpost that merely projects an estimate or a numerical fact. The second point is that HRM analytics do not focus exclusively on HR functional data but involves integrating data from different internal functions and data external to the firm, such as ROI, capital investments incurred and earningsper-share. These additional data require a consideration in view of the fact that the HR element is critical to business success. Thirdly, HRM analytics involves using information technology to collect, manage, and report data. Fourthly, HRM analytics is about supporting people- related decisions while linking HRM decisions to business outcomes and organizational performance. This last remark about HRM analytics captures the most compelling aspect of this concept and links it to the strategic HRM literature. As pointed out by Marler and Boudreau [2017], HRM analytics has the potential to connect HRM processes and decisions with organizational performance; this is indeed an avenue to elevating HRM to playing a more strategic role and joining other business functions at the strategy table thus assisting better the connectivity between human capital and firm performance (e.g. [Crook et al. 2011]).

Of course, introducing HRM analytics requires HR practitioners to develop three important, although not mutually exclusive, skill sets: an understanding of data treatment and analysis, the use of IT, and a deep understanding of other business areas like finance. We do not see these three skill sets as separate but rather complementing each other and perhaps should represent the modern HRM practitioner's competency luggage. The first, data analysis, is often quoted as the most frequently cited reason why HRM Analytics is not more widely adopted. The shortage of analytically skilled HRM professionals makes it difficult for such analytics to be introduced with a degree of conviction within the role of HRM. Unlike other areas of business, HRM professionals seem to be less conversant with number crunching and analysis of data patterns [Marler, Boudreau 2016]. Smith [2013, p. 4] specifically argues that "Human resources is one of the last departments to fully leverage its data". In his book 'The New HR Analytics', Jac Fitz-Enz does not mince words and states clearly that “...the problem was that HR didn't know, and never talked about, the value they were generating because they couldn't they had no language for it. All their terms were qualitative, subjective and equivocal" [Fitz-Enz 2010, p. xii]. Rousseau and Barends [2011] state clearly that becoming an evidence-based HRM professional requires the ability to see through the data using appropriate analysis and developing correct metrics.
The second, use of IT, requires that HRM practitioners are IT savvy. Bassi [2011] predicts that in the absence of the necessary IT acumen (i.e. how to use analytic software tools such as EXCEL, SPSS, LISREL, etc.) it is highly unlikely that HRM analytics will become a resident within the field of data-driven management. Levenson [2011] identifies the specific analytical competencies needed for HRM professionals to perform HRM effectively. These are basic data analyses, intermediate data analyses, basic multivariate models, advanced multivariate models, data preparation, root cause analysis, research design, survey design, and quantitative data collection and analysis. According to a survey of HRM analytics [Levenson, Lawler, Boudreau 2005], the higher level statistical skills needed to establish business impact are not in high demand but the bad news is that even at this low level of demand there is an inadequate supply. In fact, in that survey less than one third of HRM analytics professionals reported having competency in advanced multivariate statistics and that proportion drops to only $3 \%$ when only considering HRM professionals not specifically hired for HRM analytics. The third area that requires emphasis is the ability of HRM professionals to 'connect' through their work with other important departments of the business. Rasmussen and Ulrich [2015] argue that in addition to a shortage of technical skills, evidence suggests that HRM leaders with a clear business focus are also in short supply. The line of argument here is that appropriate collaboration between HRM practitioners and others in disciplines such as finance, operations, marketing, and engineering may be key to developing the logical frameworks for HRM analytics that can engage key decision-makers and connect more clearly to organizational outcomes (c.f. [Crook et al. 2011]).

This is not a cause to despair. Like all other fields of management, HRM is evolving and needs to adapt to the changing work topography. Future HRM practitioners will be certainly better positioned to tackle challenges and be 'useful' if they embrace these competency sets. So far, studies related to HRM are disappointing and further analysis is warranted to explore these three elements in developing more effective and organizationwide impactful HRM practitioners.

\section{Conclusion}

Having reviewed the value of HRM analytics within an evidence-based decision-making framework and also evaluated the state of this area within its broader potential impact on organizational outcomes, one may conclude that the field offers promise to up-andcoming HRM practitioners to make that significant 
added-value to firm performance through providing important insights related to business trends and organizational outcomes. Future research should examine a number of issues, essentially three. First, how do current HRM practitioners approach data and adopt data in their decision-making processes? Second, how do current practitioners score on the various skill-sets discussed in this paper and how would acquisition of these fulfil their improved performance? Third, how can HRM become a more strategically positioned profession on the basis of the utilisation of data and analytics?

We do not profess that HRM analytics is the single way forward, but it surely makes a trustworthy companion within the skill set and mental repertoire of contemporary HRM practitioners. The inclusion and appreciation of HRM analytics within the applied curriculum of HR managers will undoubtedly show poor Cinderella to be a magnificent princess who does need not wait to be rescued by a prince or a fairy godmother, and really is worthy of attending the ball.

\section{Bibliography}

Ashford S., George E., Batt R., 2007, Old assumptions, new work: The opportunities and challenges of research on nonstandard employment, Academy of Management Annals, vol. 1, pp. 65-117.

Baba V.V., HakemZadeh F., 2012, Toward a theory of evidence based decision making, Management Decision, vol. 50, no 5, pp. 832-867.

Barends E., Rousseau D. M., Briner R.B., 2014, Evidence-Based Management: The basic principles, Centre for Evidence-Based Management, Amsterdam, The Netherlands.

Barends E., Villanueva J., Briner R.B., ten Have S., 2015, Managers' attitudes and perceived barriers to evidence-based management: an international survey, [in;] Barends E. (ed.), In Search of Evidence, Centre for Evidence-Based Management, Amsterdam, The Netherlands, pp. 143-178.

Bassi L., 2011, Raging debates in HR analytics, People + Strategy, vol. 34, no 2, pp. 14-18.

Bassi L. Carpenter R., McMurrer D., 2012, HR Analytics Handbook, Reed Business, Amsterdam.

Bazerman M.H., Moore D.A., 2013, Judgement in Managerial Decision Making ( $8^{\text {th }}$ ed.), John Wiley, Hoboken, NJ.

Bezzina F., Cassar V., Tracz-Krupa K., Przytula S., Tipuric D., 2017, Evidence-based human resource management practices in three EU developing member states: can managers tell truth from fallacy?, European Management Journal, in press.

Bhalla V., Dyrchs S., Strack R., 2017, Twelve Forces that will radically change how Organizations Work, Boston Consulting Group.

Bondarouk T., Brewster C., 2016, Conceptualising the future of HRM and technology research, The International Journal of Human Resource Management, vol. 27, no 21, pp. 2652-2671.

Bowen D.E., Ostroff C., 2004, Understanding HRM-firm performance linkages: the role of the 'strength' of the HRM system, Academy of Management Review, vol. 29, pp. 203-221.
Bridges W., 1995, Jobshift, NB Publishing, London.

Briner R.B., 2007, Is HRM evidence-based and does it matter?, IES Opinion: Institute for Employment Studies.

Briner R.B., Barends E., 2016, The role of scientific findings in evidence-based HR, People + Strategy, vol. 39, no 2, pp. 16-20.

Briner R.B., Denyer D., Rousseau D., 2009, Evidence-Based Management: concept clean up time? Academy of Management Perspectives, vol. 23, no 4, pp. 19-32.

Burkholder N.C., Golas S., Shapiro J., 2007, Ultimate Performance: Measuring Human Resources at Work, John Wiley \& Sons, Hoboken, NJ.

Cappelli P., Keller J.R., 2013, Classifying work in the new econo$m y$, Academy of Management Review, vol. 38, no 4, pp. 575-586 .

Clinton M., Guest D.E., 2013, Testing universalistic and contingency HRM assumptions across job levels, Personnel Review, vol. 42, pp. 529-551.

Combs J., Liu Y., Hall A., Ketchen D., 2006, How much do high-performance work practices matter?, A meta-analysis of their effects on organizational performance, Personnel Psychology, vol. 59, pp. 501-528.

Crook T.R., Yodd S.Y., Combs J.G., Woehr D.J., Ketchen D.J., 2011, Does human capital matter?, A meta-analysis of the relationship between human capital and firm performance, Journal of Applied Psychology, vol. 96, no 3, pp. 443-456.

Delery J.E., Doty D.H., 1996, Modes of theorizing in strategic human resource management: Test of universalistic, contingency and configurational performance predictions, Academy of Management Journal, vol. 39, pp. 802-835.

Dik B.J., Byrne Z., Steger M.F. (ed.), 2013, Purpose and Meaning in the Workplace, American Psychological Association, Washington, D.C.

Donaldson L., 2012, Evidence-Based Management using organizational facts, [in:] Rousseau D.M. (ed.), The Oxford Handbook of Evidence-Based Management, Oxford University Press, Oxford, UK, pp. 249-261.

Edwards M.R., Edwards K., 2016, Predictive HR Analytics: Mastering the HR Metric, Kogan Page, London.

Farndale E., Sanders K., 2017, Conceptualizing HRM system strength through a cross-cultural lens, The International Journal of Human Resource Management, vol. 28, no 1, pp. 132-148.

Fitz-Enz J., 2010, The New HR Analytics, American Management Association, New York.

Grant A., Parker S., 2009, Redesigning work design theories: the rise of relational and proactive perspectives, Academy of Management Annals, vol. 3, pp. 317-375.

Gratton L., 2000, Living Strategy: putting people at the heart of corporate purpose, Pearson Education Ltd., London, UK.

Herriot P., Pemberton C., 1995, New deals, John Wiley \& Sons, Chichester.

Hirsh W., Briner R.B., 2011, Evidence-based HR: from fads to facts?, Corporate Research Forum (Report).

Hofmann D.A., Frese M. (ed.), 2011, Errors in Organizations, US: Routledge, New York,

Humphrey S.E., Nahrgang J.D., Morgeson F.P., 2007, Integrating motivational, social, and contextual work design features: a meta-analytic summary and theoretical extension of the work design literature, Journal of Applied Psychology, vol. 92, pp. 1332-1356.

Jackson S.E., Schuler R.S., 2003, Managing Human Resources through Strategic Partnerships (8th ed.), Southwestern, Mason, $\mathrm{OH}$. 
Jackson S.E., Schuler R.S., Jiang K., 2014, An aspirational framework for strategic Human Resource Management, The Academy of Management Annals, vol. 8, no 1, pp. 1-56.

Jiang K., Lepak D., Hu J., Baer J., 2012, How does human resource management influence organizational outcomes?, A meta-analytic investigation of mediating mechanisms, Academy of Management Journal, vol. 55, pp. 1264-1294.

Kipping M., Üsdiken B., 2014, History in organization and management theory: more than meets the eye, The Academy of Management Annals, vol. 8, no 1, pp. 535-588.

Latham G.P., 2007, A speculative perspective on the transfer of behavioral science findings to the workplace: "The times they are a-changin", Academy of Management Journal, vol. 50, no 5, pp. 1027-1032.

Lawler III, E.E., Levenson A., Boudreau J.W., 2004, HR Metrics and Analytics: Use and Impact, Human Resource Planning, vol. 27, p. 27-35.

Learmonth M., 2006, Is there such a thing as 'Evidence-Based Management'?: a commentary on Rousseau's 2005 Presidential Address, Academy of Management Review, vol. 31, no 4, pp. 1089-1093.

Learmonth M., Harding N., 2016, Evidence-Based Management: the very idea, Public Administration, vol. 84, no 2, pp. 245-266.

Levenson A., 2011, Using targeted analytics to improve talent decisions, People \& Strategy, vol. 34, pp. 34-43.

Levenson A., Lawler III, E. E., Boudreau J.W., 2005, Survey on $H R$ Analytics and HR transformation: fFeedback report, Center for Effective Organizations, University of Southern California, Los Angeles, CA.

Marler J.H., Boudreau J.W., 2017, An evidence-based review of HR Analytics, The International Journal of Human Resource Management, vol. 28, no 1, pp. 3-26.

Mondare S., Douthitt S., Carson M., 2011, Maximizing the impact and effectiveness of HR Analytics to drive business outcomes, People \& Strategy, vol. 34, pp. 20-27.

Ostroff C., Bowen D.E., 2016, Reflections on the 2014 decade award: is there strength in the construct of HR system strength? Academy of Management Review, vol. 41, pp. 196-214.
Pfeffer J., 1998, The Human Equation: building profits by putting people first, Harvard Business School Press, Boston, MA.

Pfeffer J., Sutton R.I., 2006, Evidence-based management, Harvard Business Review (January issue), pp. 63-74.

Porter L.W., Schneider B., 2014, What was, what is and what may be in $O P / O B$, The Annual Review of Organizational Psychology and Organizational Behavior, vol. 1, pp. 1-21.

Rasmussen T., Ulrich, D., 2015, Learning from practice: how HR analytics avoids being a management fad, Organizational Dynamics, vol. 44, pp. 236-242.

Rousseau D.M., 2006, Is there such a thing as EBMgt?, Academy of Management Review, vol. 31, pp. 256-269.

Rousseau D.M., 2007, A sticky, leveraging, and scalable strategy for high-quality connections between organizational practice and science, Academy of Management Journal, vol. 50, no 5, pp. 1037-1042.

Rousseau D.M., Barends E., 2011, Becoming an evidence-based $H R$ practitioner, Human Resources Management Journal, vol. 21, no 3, pp. 221-235.

Rousseau D.M., McCarthy S., 2007, Evidence-based management: educating managers from an evidence-based perspective, Academy of Management Learning and Education, vol. 6, pp. 94-101.

Rynes S.L., Colbert A.E., Brown K.G., 2002, HR professionals' beliefs about effective human resource practices: correspondence between research and practice, Human Resource Management, vol. 41, no 2, pp. 149-174.

Sanders K., van Riemsdijk M. Groen B., 2008. The gap between research and practice: a replication study on the HR professionals' beliefs about effective human resource practices, The International Journal of Human Resource Management, vol. 19, no 10, pp. 1976-1988.

Smith T., 2013, HR Analytics: The What, Why and How, Tracey Smith Copyright.

Sparrow P.R., Cooper C.L., 2003, The Employment Relationship: key challenges for HR, Butterworth-Heinemann, Oxford, UK.

Weick K., 1995, Sense-making in Organizations, Sage Publications, Thousand Oaks, California.

\section{HRM OPARTE NA FAKTACH Z WYKORZYSTANIEM ANALITYKI: ZMNIEJSZENIE SKLONNOŚCI HRM DO ZOSTANIA KOPCIUSZKIEM}

Streszczenie: Praktycy HRM często z trudem wprowadzają funkcję strategiczną w swoich organizacjach. Na podstawie HRM opartego na faktach $w$ artykule podkreślono znaczenie danych dla lepszego podejmowania decyzji w HRM, ponieważ nieuregulowane procesy decyzyjne mogą prowadzić do błędów. Często menedżerowie nie mają czasu na ocenę danych i/lub nie posiadają wystarczających danych. Niestety wiele badań pokazuje, że praktyka HRM nadal w znacznym stopniu opiera się na wiedzy potocznej, na błędnym rozumieniu oraz na behawiorystycznych/strategicznych założeniach o tym, co „powinno najlepiej działać”. Zarazem przeważa opinia, że działania HRM mają wpływ na wyniki i te relacje są dość powszechne, a zatem wymagają usprawnienia decyzji poprzez właściwe użycie danych, od dawna będące przedmiotem rozważań. W artykule wskazano istotne elementy analityki HRM i podkreślono, że jej użycie wymaga od specjalistów HR rozwinięcia trzech istotnych zespołów umiejętności: zrozumienia użycia i analityki danych, korzystania z IT oraz wiedzy o innych sferach biznesu. Ponieważ, tak jak inne dziedziny zarządzania, HRM także ewoluuje, konieczna jest adaptacja do zmian w pracy, by zwiększyć jego strategiczne znaczenie.

Słowa kluczowe: praktycy HRM, pomiary HRM, analityka HRM, podejmowanie decyzji, dane, HRM oparte na faktach. 